\title{
HUBUNGAN KARAKTERISTIK INDIVIDU, PENILAIAN KINERJA DAN KARAKTERISTIK ORGANISASI DENGAN PENGEMBANGAN KARIER PADA PT SUN LIFE FINANSIAL CABANG SINGARAJA
}

\author{
Ni Luh Suma Widari \\ Jurusan Pendidikan Ekonomi \\ Universitas Pendidikan Ganesha \\ Singaraja, Indonesia \\ e-mail: sumawidariid@gmail.com
}

\begin{abstract}
Abstrak
Penelitian ini bertujuan untuk mengetahui hubungan karakteristik individu, penilaian kinerja dan karakteristik organisasi dengan pengembangan karier karyawan pada PT SUN Life Finansial Cabang Singaraja. Jenis penelitian ini merupakan penelitian kuantitatif. Metode pengumpulan data dalam penelitian ini menggunakan kuesioner. Metode analisis data menggunakan analisis korelasi dengan bantuan SPSS 21.0 for Windows. Hasil penelitian menunjukkan bahwa terdapat hubungan yang positif antara variabel karakteristik individu, penilaian kinerja dan karakteristik organisasi terhadap pengembangan karier karyawan pada PT SUN Life Finansial Cabang Singaraja yang didukung dengan hasil pengujian hipotesis menggunakan uji T-Test bahwa nilai thitung $>$ nilai t-tabel sehingga hipotesis diterima. yang menunjukkan bahwa nilai $(x 1)$ $\mathrm{t}$-hitung 2,118 $>1,671 \mathrm{t}$-tabel atau $\mathrm{p}$-value $=0,037<\alpha=0,050$. Maka $\mathrm{H}_{0}$ ditolak dan $\mathrm{H}_{\mathrm{a}}$ diterima, nilai (x2) adalah t-hitung 2,250 $>1,671 \mathrm{t}$-tabel atau $\mathrm{p}$-value $=0,027<\alpha=0,050$. Maka $\mathrm{H}_{0}$ ditolak dan $\mathrm{H}_{\mathrm{a}}$ diterima, artinya Nilai (x3) t-hitung 2,526 $>1,671 \mathrm{t}$-tabel atau $\mathrm{p}$ value $=0,014<\alpha=0,05$. Maka $\mathrm{H}_{0}$ ditolak dan $\mathrm{H}_{\mathrm{a}}$ diterima, artinya hipotesis diterima yaitu terdapat hubungan yang positif antara karakteristik organisasi dengan pengembangan karier
\end{abstract}

Kata kunci: karakteristik individu, penilaian kinerja, karakteristik organisasi dan pengembangan karier

\begin{abstract}
This research was to determine the correlation of individual characteristics, performance appraisal and organizational characteristics with employee career development in PT SUN Life Finance Branch Singaraja. This type of research is a quantitative research. Methods of data collection in this study using questionnaires. Methods of data analysis using correlation analysis with the help of SPSS 21.0 for Windows. The results showed that there was a positive correlation between individual characteristic variable, performance appraisal and organizational characteristic toward employee career development at PT SUN Life Finansial Branch Singaraja supported by hypothesis test result using T-Test that $t$-count value> t-table value so the hypothesis is accepted. which shows that the value Then $\mathrm{HO}$ is rejected and $\mathrm{Ha}$ is accepted, the value (x2) is 2,250 t count $>1,671 \mathrm{t}$-table or $\mathrm{p}$-value $=0,027<\alpha=0,050$. Then $\mathrm{HO}$ is rejected and $\mathrm{Ha}$ is accepted, meaning Value $(\times 3)$ counts $2.526>1.671 \mathrm{t}$ table or $p$-value $=0.014<\alpha=0.05$. Then $\mathrm{HO}$ is rejected and $\mathrm{Ha}$ is accepted, meaning that the hypothesis is accepted that there is a positive relationship between organizational characteristics employee career development
\end{abstract}

Keywords : Individual Characteristics, performance assessment, Characteristics of organization and Career development 


\section{PENDAHULUAN}

Karyawan merupakan asset yang sangat vital bagi perusahaan. Karena kinerja yang mereka lakukan sangat mempengaruhi efektivitas kinerja perusahaan. Oleh karena itu peningkatan kinerja karyawan menjadi fokus utama unit manajemen sumber daya manusia. Mereka berusaha mengembangkan potensi-potensi yang dimiliki oleh individu agar mereka termotivasi untuk memberikan kontribusi terbaik demi pencapaian tujuan-tujuan perusahaan, kinerja karyawan merupakan hasil dari suatu proses atau aktivitas pada fungsi tertentu yang dilaksanakan oleh seseorang baik sebagai individu maupun sebagai anggota dari suatu kelompok atau organisasi pada periode tertentu berdasarkan standar yang telah ditetapkan, dan hasilnya dapat dinikmati sendiri maupun oleh kelompok dalam perusahaan (Rivai \& Sagala, 2013:11).

Organisasi yang baik, tumbuh dan berkembang akan menitikberatkan pada sumber daya manusia (human resources) guna menjalankan fungsinya dengan optimal, khususnya menghadapi dinamika perubahan lingkungan yang terjadi. Dengan demikian, kemampuan teknis, teoritis, konseptual, moral dari para pelaku organisasi/perusahaan di semua tingkat (level) pekerjaan sangat dibutuhkan. Selain itu, pula kedudukan sumber daya manusia pada posisi yang paling tinggi berguna untuk mendorong perusahaan menampilkan norma perilaku, nilai dan keyakinan sebagai sarana penting dalam peningkatan kinerjanya (Yolandari, 2012:1).

Simamora (2014:394) menyatakan bahwa "Faktor-faktor yang mempengaruhi pengembangan karier karyawan adalah Karakteristik Individu, penilaian kinerja dan karakteristik organisasi”. lebih lanjut menurut Husein (2012:36) bahwa "Karakteristik Individu yang dimiliki karyawan mencirikan antara satu orang dengan orang lain berbeda adalah karena masing-masing individu memiliki potensi dan kebutuhan yang berbeda. Oleh karena itu, pihak manajemen dituntut untuk memahami perilaku individu agar selaras dengan tujuan organisasi.
Karakteristik Individu yang dibawa dalam lingkungan kerja akan berpengaruh terhadap kinerjanya". Lebih lanjut Handoko (2013:130) menyatakan bahwa "pengembangan karier merupakan upaya pribadi seseorang karyawan (Karakteristik Individu yang dimiliki) untuk mencapai suatu rencana karier".

Septiawati (2012) menyatakan bahwa "pengembangan karier ditujukan agar karyawan mempunyai kemampuan yang lebih tinggi dari kemampuan yang dimiliki sebelumnya sehingga dapat mengetahui fungsi dan peranan serta tanggung jawabnya di dalam lingkungan kerja. Dengan pengembangan karier juga diharapkan dapat mencapai tingkat kepuasan yang lebih tinggi". Perusahaan berusaha untuk menumbuhkan kepuasan kerja yang sehat di mana hak dan kewajiban karyawan diatur sedemikian rupa selaras dengan fungsi, peranan dan tanggung jawab karyawannya sehingga karyawan dapat berpartisipasi dalam perusahaan.

Selain Karakteristik Individu, penilaian kinerja juga mempengaruhi pengembangan karier pegawai. Kinerja terhadap pegawai merupakan tolak ukur utama dalam pengembangan SDM. Mangkuprawira (2014:166), menyatakan "penilaian kinerja sebagai proses yang dilakukan suatu organisasi dalam mengevaluasi kinerja pekerjaan seseorang yang bisa mempengaruhi pengembangan karier pegawai". Sementara itu Menurut Hasibuan (20014:93) bahwa "kinerja karyawan sebagai suatu hasil kerja yang dicapai seseorang dalam melakukan tugas-tugas yang dibebankan kepadanya yang didasarkan pada kecakapan, pengalaman, dan kesungguhan serta ketepatan waktu dalam rangka melaksanakan pengembangan karier pegawai".

Karakteristik organisasi juga dapat mempengaruhi pengembangan karier karyawan. Thomson (dalam Hardjana, 2012:136) mengatakan bahwa "karakteristik organisasi adalah sejumlah orang yang melakukan tugas dan pekerjaan tertentu untuk masing-masing orang atau kelompok orang secara rasional, non pribadi untuk mencapai 
tujuan tertentu". Simamora (2014:507) mengatakan bahwa "karakteristik organisasi terdiri atas sumber daya, iklim, tujuan dan struktur organisasi mempengaruhi manajemen karier yang akhirnya berdampak pada pengembangan karier".

Sumber daya manusia memiliki karakternya masing-masing. Karakteristik Individu yang dimiliki karyawan mencirikan antara satu orang dengan orang lain berbeda adalah karena masing-masing individu memiliki potensi dan kebutuhan yang berbeda. Oleh karena itu pihak manajemen dituntut untuk memahami perilaku individu agar selaras dengan tujuan organisasi. Karakteristik Individu yang dibawa dalam lingkungan kerja akan berpengaruh terhadap kinerjanya. (Husien, 2012:36).

Menurut Sumarsono (2012:227) bahwa "faktor yang mempengaruhi pengembangan Karier adalah Karakteristik Individu". Lebih lanjut Handoko (2013:130) menyatakan bahwa "pengembangan karier merupakan upaya pribadi seseorang karyawan (Karakteristik Individu yang dimiliki) untuk mencapai suatu rencana karier".

Thoha (2012:30) menyatakan berkaitan dengan Karakteristik Individu, bahwa "individu membawa ke dalam tatanan organisasi, kemampuan, kepercayaan, pribadi, dan penghargaan kebutuhan dan pengalaman masa lainnya. Ini semua adalah karakteristik yang dimiliki individu dan karakteristik ini akan memasuki suatu lingkungan baru, yaitu organisasi yang berpengaruh terhadap pengembangan karier seseorang".

Berdasarkan penelitian yang

dilakukan oleh Tajuddin (2012:32) diperoleh hasil bahwa "pelaksanaan penilaian kinerja karyawan amat penting dilakukan untuk membantu pihak manajemen dalam mengambil keputusan mengenai pemberian bonus, kenaikan jabatan, kenaikan gaji, pemindahan pada unit yang sama maupun pemutusan hubungan kerja dengan perusahaan". Untuk itu dibutuhkan informasi yang penting bagi keputusan penempatan tersebut adalah melalui penilaian kinerja. Dari penilaian prestasi ini dapat diketahui apakah penempatannya sudah tepat ataukah perlu dipindahkan ke bagian lain atau mungkin dipromosikan. Apabila ada kemungkinan untuk dipromosikan, maka karyawan diberi pendidikan lanjutan atau latihan tambahan yang diperlukan untuk menduduki jabatan yang direncanakan akan diduduki. Maka apabila jabatan yang dipersiapkan untuk karyawan ada yang kosong, maka karyawan telah siap untuk dipromosikan.

Menurut Hasibuan (2014) "salah

satu upaya yang diharapkan dapat meningkatkan kinerja karyawan adalah melalui program pengembangan pegawai. Pengembangan pegawai adalah suatu usaha untuk meningkatkan kemampuan teknis, teoritis, konseptual, dan moral pegawai sesuai kebutuhan pekerjaan/jabatan melalui pendidikan dan latihan, promosi dan pemindahan pegawai. Upaya ini pada dasarnya bertujuan untuk memperbaiki dan meningkatkan efektivitas pelaksanaan pekerjaan oleh pegawai sehingga mampu memberikan kontribusi terbaik dalam mewujudkan tujuan organisasi. Tingkat efektivitas ini ditentukan oleh kemampuan pegawai yang mencakup aspek pengetahuan, keterampilan, sikap, kerja sama dalam tim, kemampuan pemecahan masalah dan berbagai kemampuan manajerial lainnya.

Menurut Simamora (2014:507) bahwa "bagian dari karakteristik organisasi yang meliputi sumber daya, iklim, tujuan dan struktur organisasi memengaruhi manajemen karier yang akhirnya berdampak pada pengembangan karier". Hal ini didukung penelitian yang dilakukan oleh Nizwar (2014) bahwa "karakteristik organisasi berpengaruh positif dan signifikan terhadap pengembangan karier karyawan".

Salah satu perusahaan yang menerapkan pengembangan karier melalui Karakteristik Individu dan penilaian kinerja adalah PT SUN Life Finansial Cabang Singaraja. Asuransi Jiwa Sunlife Finansial tergolong asuransi yang cukup dikenal masyarakat. Gambaran kinerja tersebut menjadi acuan perusahaan dalam mengembangkan karier karyawan melalui penilaian kinerja dan Karakteristik Individu 
yang dimilik karyawan sehingga dengan penilaian kinerja, maka manajer dapat mengetahui seberapa mampu karyawan mengerjakan tugas dan tanggung jawab yang diberikan kepadanya. Dengan demikian perusahaan dapat menentukan balas jasa yang layak baginya. Dalam penilaian kinerja sering muncul berbagai permasalahan salah satunya adalah tidak semua penilaian sesuai dari semua situasi dan kondisi nyata.

Menurut Mathis (2012:64)

"karakteristik individu adalah ciri khas atau sifat khusus yang dimiliki seseorang karyawan yang dapat menjadikan dirinya memiliki kemampuan yang berbeda dengan orang lain untuk mempertahankan dan memperbaiki kerja di dalam organisasinya".

$$
\text { Menurut Husein }
$$

"Karakteristik individu yang mencirikan antara satu orang dengan orang lain berbeda adalah karena masing-masing individu memiliki potensi dan kebutuhan yang berbeda. Oleh karena itu pihak manajemen dituntut untuk memahami perilaku individu agar selaras dengan tujuan organisasi".

$$
\text { Lebih lanjut Thoha (2012) }
$$

menyatakan bahwa Karakteristik individu adalah perilaku atau karakter yang ada pada diri seorang karyawan baik yang bersifat positif maupun negatif. Karakteristik-karakteristik ini sangat beragam, setiap perusahaan tentunya dapat memilih seorang karyawan yang mempunyai kriteria yang baik dan karakteristik ini juga harus sesuai dengan apa yang diinginkan perusahaan. Karakteristik pribadi dapat dilihat dari Keahlian, dan Pendidikan.

$$
\text { Menurut Hasibuan (2014:105) }
$$

bahwa "kinerja adalah suatu hasil kerja yang dicapai seseorang dalam melakukan tugas-tugas yang dibebankan kepadanya yang didasarkan pada kecakapan, pengalaman, dan kesungguhan serta ketepatan waktu". Kinerja dipengaruhi oleh tiga faktor yakni kemampuan dan minat seorang pekerja, kemampuan dan penerimaan atas penjelasan delegasi tugas dan peran, serta tingkat motivasi seorang pekerja.
Mangkuprawira

menyatakan bawah "penilaian kinerja sebagai proses yang dilakukan perusahaan dalam mengevaluasi kinerja pekerjaan seseorang". Dari hasil pembahasan di atas, maka pelaksanaan penilaian kinerja di dalam suatu organisasi sangatlah penting. Dengan penilaian prestasi pihak perusahaan dapat mengambil tindakan yang dapat dilakukan untuk meningkatkan keterampilan dan mengembangkan karyawannya, sesuai dengan potensi dan keterampilan dari karyawan tersebut.

Menurut Sedarmayanti (2012) penilaian kinerja karyawan dapat diukur dengan menggunakan 5 (lima) indikator yaitu : Pertama, kuantitas kerja yaitu jumlah kerja yang dilakukan dalam suatu periode waktu yang ditentukan. Aspek kuantitatif yang perlu diperhatikan dalam penilaian kinerja mencakup lamanya waktu yang digunakan dan banyaknya kesalahan yang dilakukan serta volume pekerjaan yang dilakukan pada hari kerja normal. Kinerja karyawan dapat dicerminkan dari kuantitas kerja yang dicapai.

Kedua, kualitas kerja yaitu kualitas kerja yang dicapai berdasarkan syaratsyarat kesesuaian dan kesiapan. Aspek kualitas dari pekerjaan yang perlu diperhatikan dalam penilaian kerja mencakup, kemampuan untuk mengkoordinasikan, kemampuan untuk menganalisis, dan kemampuan untuk mengevaluasi kualitas pekerjaan yang meliputi keahlian dan kesempurnaan pekerjaan.

Ketiga, pengetahuan kerja adalah kejelasan pemahaman pegawai mengenai faktor-faktor yang berhubungan dengan pekerjaan. Pengetahuan pekerjaan merupakan informasi yang berhubungan dengan pekerjaan yang memungkinkan individu atau karyawan terpuaskan dengan kinerja pekerja. Pengetahuan pekerjaan berkaitan dengan keahlian dan kemampuan yang dimiliki karyawan.

Keempat, kreativitas yaitu keaslian gagasan yang dimunculkan dari tindakantindakan untuk menyelesaikan persoalanpersoalan yang timbul. Dimensi dari kreativitas dalam penilaian kinerja yaitu 
menggunakan istilah adaptability yaitu kemampuan karyawan untuk mengikuti perubahan dan belajar terus menerus. Kreatifitas karyawan merupakan sikap dan perilaku karyawan di dalam menggunakan kemampuan berpikir yang rasional ke arah mencari berbagai alternative di dalam memecahkan berbagai masalah dan kendala untuk diubah menjadi peluang melalui penemuan baru sebagai hasil cara berpikir rasional dan kreatif.

Kelima, kerja sama yaitu merupakan kesediaan karyawan untuk bekerja sama dengan orang lain atau sesama karyawan dan bawahan untuk mencapai tujuan organisasi. Kerjasama dititik beratkan kepada kesediaan untuk bekerja sama dengan para pegawai yang terkait dengan pelaksanaan tugas dan tanggung jawab, serta kesediaan untuk memotivasi pegawai lain untuk bekerja sama. Kerja sama juga berkaitan dengan kemampuan karyawan dalam menghargai hasil kerja dari rekan sekerja.

Menurut Thomson (dalam Hardjana, 2012:136) "karakteristik organisasi adalah sejumlah orang yang melakukan tugas dan pekerjaan tertentu untuk masing-masing orang atau kelompok orang secara rasional, non pribadi untuk mencapai tujuan tertentu". Simamora (2014:507) mengatakan bahwa "sumber daya, iklim, tujuan dan struktur hhhorganisasi mempengaruhi manajemen karier yang akhirnya berdampak pada pengembangan karier".

Wahab (2012:4) "menjelaskan beberapa karakteristik dari organisasi di antaranya adalah: sebuah entitas sosial, bertujuan atau diarahkan oleh tujuan (goal directed), memiliki sistem kegiatan terstruktur yang disengaja dan, dengan batas-batas yang jelas".

Menurut Simamora (2014:507) "Organisasi harus mampu menciptakan rangsangan dan tantangan dalam penugasan pekerjaan yang dikaitkan dengan sukses karier. Tantangan tersebut harus merangsang seseorang untuk berkinerja dengan baik dalam tahun-tahun berikutnya".

Berdasarkan teori Simamora (2014:507) tersebut maka terdapat tiga indikator yang digunakan untuk mengukur karakteristik organisasi yaitu : Pertama, sumber daya organisasi. Sumber daya organisasi penting untuk sebuah pengembangan karier. Sumber daya organisasi merupakan modal utama organisasi, yang dimaksud adalah sumber daya finansial (keuangan), sumber daya waktu dan sumber daya manusia. Menurut Simamora (2014:507) "sumber daya finansial dibutuhkan guna melibatkan karyawan dan manajer dalam aktivitas perencanaan karier dan sumber daya manusia dibutuhkan untuk konseling dan pemberian nasihat".

Kedua, iklim organisasi. Menurut Simamora (2014: 508) bahwa "organisasi harus menciptakan iklim yang mendorong manajemen karier yang komprehensif". Contohnya adalah sebuah organisasi yang mengenalkan suatu sistem penilaian kerja yang menitikberatkan pada pengembangan. Selain ketersediaan pekerjaan, jumlah informasi yang tersedia seseorang memilih sebuah organisasi berdasarkan kecocokan antara iklim organisasi sebagaimana mereka mempersepsikan dalam karakteristik pribadi mereka. Dalam iklim seperti itu pimpinan pusat akan lebih mengenali pimpinan atas seberapa baiknya mereka mengembangkan bawahan mereka. Pimpinan organisasi juga merupakan bagian dari iklim organisasi yang dapat mengadakan program pengembangan karier yang membantu perencanaan karier pegawai dengan cara memberitahukan pegawai mengenai pekerjaan yang ada sekarang dan masa mendatang. Dari uraian di atas iklim organisasi adalah kondisi lingkungan kerja yang mempengaruhi dan menunjang aktivitas individu di dalamnya.

Ketiga, struktur organisasi. Menurut Handoko (2013:169) "Struktur organisasi (desain organization) dapat didefinisikan sebagai mekanisme formal dengan kemampuan organisasi". Struktur organisasi menunjukkan kedudukan, tugas, wewenang dan tanggungjawab yang berbeda-beda. Struktur ini mengandung unsur sosialisasi kerja, standarisasi, koordinasi, sentralisasi atau desentralisasi dalam pembuatan keputusan. lebih lanjut Flippo (2012) 
menyatakan bahwa hasil langsung dari proses organisasi adalah penciptaan struktur organisasi. Struktur ini adalah kerangka dasar dari hubungan formal yang telah disusun. Maksud dari struktur itu adalah untuk membantu dalam mengatur dan mengarahkan usaha-usaha yang dilakukan dalam organisasi sehingga usaha tersebut terkoordinir dan konsisten dengan sasaran organisasi.

Pengertian pengembangan karier itu sendiri adalah proses pelaksanaan (implementasi) perencanaan karier. Menurut Handoko (2013:123) bahwa "pengembangan karier adalah peningkatan-peningkatan pribadi yang dilakukan seseorang untuk mencapai suatu rencana karier".

Mathis \& Jackson (2012:27) menjelaskan definisi "pengembangan karier sebagai pertumbuhan kemampuan yang terjadi jauh melampaui apa yang dituntut dalam suatu pekerjaan dan dalam hal ini sumber daya manusia berperan penting dalam maju mundurnya suatu organisasi". Lebih lanjut Notoatmodjo (2012:2) melihat pengertian "pengembangan karier secara makro adalah suatu proses peningkatan kualitas atau kemampuan manusia dalam rangka mencapai mutu tugas pengembangan, sedangkan pengembangan karier secara mitos adalah perencanaan pendidikan, pelatihan dan pengelolaan tenaga atau karyawan untuk mencapai suatu hasil yang optimal".

Menurut Simamora (2014:392) "pengembangan karier adalah suatu kondisi yang menunjukkan adanya peningkatan-peningkatan status seseorang dalam organisasi dalam jalur karier yang telah ditetapkan dalam organisasi yang bersangkutan".

Menurut konsep Simamora (2014), yang menjadi indikator pengembangan karier adalah perencanaan karier dan manajemen karier dimana dari kedua konsep tersebut, dalam kemampuan manajerial seseorang mencari dan menghargai kesempatan - kesempatan untuk merencanakan. Hal ini merefleksikan nilai - nilai lebih jauh untuk Karakteristik Individu antar pribadi, Karakteristik Individu analitis dan kematangan emosional. Dalam kemampuan teknis, seseorang mencari dan menghargai kesempatan untuk melatih berbagai macam bakat dan bidang - bidang Karakteristik Individu teknis. Dengan keamanan, seseorang termotivasi terutama oleh kebutuhan untuk menstabilkan situasi kariernya, sekalipun ia harus berada di bawah komando orang lain atau dia hanya melakukan pekerjaan yang kurang penting dalam organisasi.

Berdasarkan pendahuluan diatas maka penelitian ini bertujuan untuk mengetahui hubungan karakteristik Individu, penilaian kinerja dan karakteristik organisasi dengan pengembangan karier karyawan pada PT SUN Life Finansial Cabang Singaraja.

\section{METODE}

Penelitian ini termasuk dalam jenis penelitian korelasional Penelitian korelasional adalah suatu penelitian untuk mengetaui hubungan antara dua variabel atau lebih tanpa ada upaya untuk mempengaruhi variabel tersebut sehingga tidak terdapat manipulasi variabel (Faenkel \& Wallen,2008:328). Data yang digunakan dalam penelitian ini adalah data primer, yang diperoleh dengan menggunakan kuesioner kepada responden yang kemudian jawaban responden tersebut akan diklasifikasikan dalam bentuk angka. Metode Analisis data yang digunakan dalam penelitian ini adalah uji kualitas data dengan menggunakan uji validitas dan reliabilitas kemudian menggunakan analisis korelasi.

Sugiyono (2012) menyatakan bahwa "Populasi merupakan wilayah generalisasi yang terdiri dari obyek-obyek yang mempunyai kuantitas dan karakteristik tertentu, ditetapkan untuk dipelajari dan kemudian ditarik simpulannya". Populasi dalam penelitian ini adalah semua karyawan PT SUN Life Finansial Cabang Singaraja yang berjumlah 80 orang pegawai. Melihat besarnya sampel masih dalam kemampuan peneliti maka semua populasi.

Jenis data yang digunakan adalah data kuantitatif yaitu data yang dinyatakan dalam bentuk angka-angka yang dapat dihitung. Dalam penelitian ini yang 
termasuk data kuantitatif adalah jawaban kuisioner dari responden, sedangkan sumber data yang digunakan adalah data primer yaitu data penelitian yang diperoleh secara langsung dari sumber asli (tidak melalui sumber perantara) dan data dikumpulkan secara khusus untuk menjawab pertanyaan penelitian yang sesuai dengan keinginan peneliti (NurIndriantoro \& Supomo, 2002:146). Data primer dalam penelitian ini diperoleh melalui pembagian atau penyebaran daftar pertanyaan (kuisioner) yang diberikan kepada nasabah PT Sun Life Finansial Cabang Singaraja.

Teknik pengumpulan data yang digunakan dalam penelitian ini adalah teknik kuesioner yaitu cara pengumpulan data dengan menggunakan daftar pertanyaan yang disebarkan kepada responden untuk dimintai keterangan terhadap sesuatu yang dialami. Kuesioner yang akan digunakan dalam penelitian ini adalah menggunakan tipe skala likert.

Metode analisis menggunakan korelasional. Korelasional adalah suatu penelitian untuk mengetahui hubungan antar dua variabel. Sugiyono (2012:228) mengtakan "Analisis korelasi ini digunakan untuk mengetahui derajat hubungan antara variabel bebas $(X)$ dengan variabel terikat (Y)", kemudian dilanjutkan dengan pengujian hipotesis dengan menggunakan uji t-tes dan f-test. Uji t dilakukan untuk menguji signifikansi variabel bebas terhadap variabel terikat secara individual, hal ini dilakukan dengan membandingkan $t$ hitung dengan tabel, sedangkan Analisis Uji $F$ digunakan dengan tujuan untuk menguji pengaruh varibel Independen secara bersama-sama terhadap variabel dependen.

\section{HASIL DAN PEMBAHASAN Hasil}

Hubungan karakteristik Individu dengan pengembangan karier dianalisis menggunakan uji $\mathrm{t}$ dengan bantuan program SPSS Versi 21.0 For Windows. Hasil analisis tersebut menunjukkan adanya hubungan karakteristik individu dengan pengembangan karier. Adapun hasil analisis uji $t$ untuk variabel karakteristik individu dapat dilihat padaTabel

Tabel 1. Hasil Uji t Karakteristik Individu $\left(\mathrm{X}_{1}\right)$ dengan Pengembangan Karier ( $\left.\mathrm{Y}\right)$

\begin{tabular}{crrrrrr}
\hline Model & \multicolumn{2}{c}{$\begin{array}{c}\text { Unstandardized Coefficients } \\
\text { B }\end{array}$} & $\begin{array}{r}\text { Standardized Coefficients } \\
\text { Std. Error }\end{array}$ & T & & Sig. \\
\cline { 2 - 7 } & Constant) & 6,611 & 3,287 & & 2,011 &, 048 \\
X $_{1}$ &, 197 &, 093 & 272 & 2,118 &, 037 \\
\hline
\end{tabular}

Sumber : hasil output spss

Berdasarkan Tabel 1 di atas, menunjukkan bahwa t-hitung 2,118 > 1,671 $t_{\text {tabel }}$ atau $p$-value $=0,037<\alpha=0,050$. Maka $\mathrm{H}_{0}$ ditolak dan $\mathrm{H}_{\mathrm{a}}$ diterima, Artinya hipotesis diterima yaitu terdapat hubungan yang positif antara karakteristik Individu dengan pengembangan karier di PT Sun Life Finansial cabang Singaraja.

Hubungan penilaian kinerja dengan pengembangan karier dianalisis menggunakan uji $\mathrm{t}$ dengan bantuan program SPSS Versi 21.0 For Windows. Hasil analisis tersebut menunjukkan adanya hubungan penilaian kinerja dengan pengembangan karier. Adapun hasil analisis uji t untuk variabel penilaian kinerja dapat dilihat Tabel 2.
Berdasarkan Tabel 2 di bawah, menunjukkan bahwa t-hitung 2,250 > 1,671 $t_{-}$tabel atau $p$-value $=0,027<\alpha=0,050$. Maka $\mathrm{H}_{0}$ ditolak dan $\mathrm{H}_{\mathrm{a}}$ diterima, artinya hipotesis diterima yaitu terdapat hubungan yang positif antara penilaian kinerja dengan pengembangan karier di PT Sun Life Finansial cabang Singaraja.

Hubungan karakteristik organisasi dengan pengembangan karier dianalisis menggunakan uji $\mathrm{t}$ dengan bantuan program SPSS Versi 21.0 For Windows. Hasil analisis tersebut menunjukkan adanya hubungan karakteristik organisasi dengan pengembangan karier. Adapun hasil analisis uji $t$ untuk variabel 
karakteristik organisasi dapat dilihat pada

Tabel 3.

Tabel 2. Hasil uji t Penilaian Kinerja $\left(\mathrm{X}_{2}\right)$ dengan Pengembangan Karier $(\mathrm{Y})$

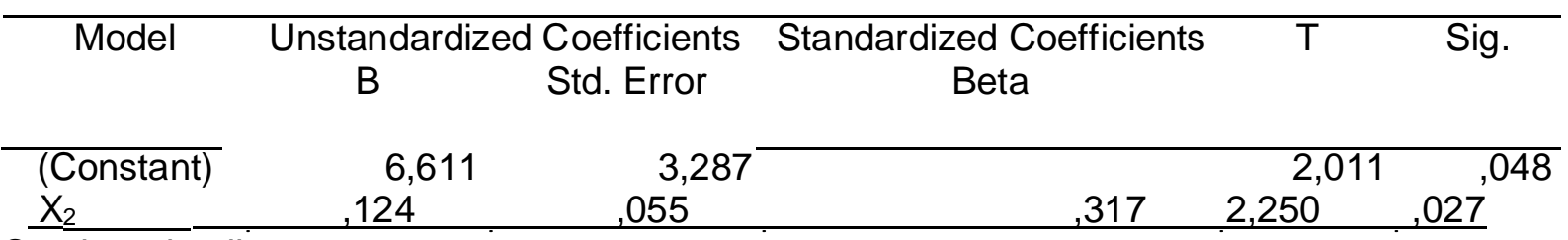

Sumber : hasil output spss

Tabel 3. Hasil uji t Karakteristik Organisasi $\left(\mathrm{X}_{2}\right)$ dengan Pengembangan Karier ( $\left.\mathrm{Y}\right)$

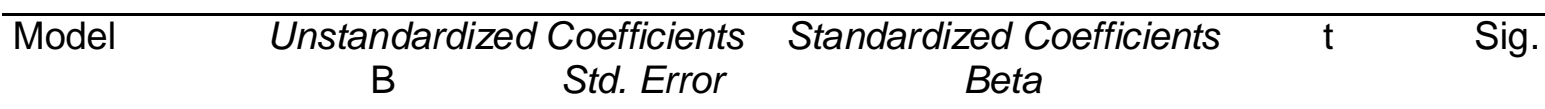

\begin{tabular}{lccccc}
\hline (Constant $)$ & 6,611 & 3,287 & 2,011 &, 048 \\
$\mathrm{X}_{3}$ & 156 &, 062 &, 280 & 2,526 &, 014 \\
\hline
\end{tabular}

Sumber : hasil output SPSS

Berdasarkan Tabel 3 maka

menunjukkan bahwa t-hitung 2,526 > 1,671

$t_{\text {tabel }}$ atau $p$-value $=0,014<\alpha=0,05$.

Maka $\mathrm{H}_{0}$ ditolak dan $\mathrm{H}_{\mathrm{a}}$ diterima, artinya hipotesis diterima yaitu terdapat hubungan yang positif antara karakteristik organisasi dengan pengembangan karier di PT Sun Life Finansial cabang Singaraja.

\section{Pembahasan}

terhadap pengembangan karier. Berdasarkan hasil penelitian menunjukkan bahwa karakteristik Individu memiliki hubungan yang lurus dan kuat terhadap pengembangan karier Di PT Sun Life Finansial cabang Singaraja sebesar 0,742 yang didukung hasil pengujian hipotesis dengan uji t-test didapatkan bahwa thitung > t-tabel $(2,118>1,671)$ sehingga hipotesis diterima yakni "terdapat hubungan yang positif antara karakteristik Individu terhadap pengembangan karier di PT Sun Life Finansial cabang Singaraja".

Hal ini menunjukkan bahwa karakteristik Individu yang dimiliki karyawan mencirikan antara satu orang dengan orang lain berbeda adalah karena masing-masing individu memiliki potensi dan kebutuhan yang berbeda. Oleh karena itu pihak manajemen dituntut untuk memahami perilaku individu agar selaras dengan tujuan organisasi. berdasarkan hal tersebut PT Sun Life Finansial Cabang Singaraja hendaknya berusaha terus meningkatkan karakteristik individu masing-masing pegawai dalam rangka peningkatan kinerja serta memperoleh pengembangan karier yang lebih baik.

Hasil ini sejalan dengan teori yang dinyatakan oleh Sumarsono (2012:227) yang menyatakan bahwa faktor yang mempengaruhi pengembangan Karier adalah Karakteristik Individu. Lebih lanjut Handoko (2013:130) menyatakan bahwa pengembangan karier merupakan upaya pribadi seseorang karyawan (Karakteristik Individu yang dimiliki) untuk mencapai suatu rencana karier.

Hubungan penilaian kinerja terhadap pengembangan karier. Berdasarkan hasil penelitian menunjukkan bahwa penilaian kinerja memiliki hubungan yang lurus dan kuat terhadap pengembangan karier Di PT Sun Life Finansial cabang Singaraja sebesar 0,725 yang didukung hasil pengujian hipotesis dengan uji t-test didapatkan bahwa thitung > t-tabel $(2,250>1,671)$ sehingga hipotesis diterima yakni "terdapat 
hubungan yang positif antara penilaian kinerja terhadap pengembangan karier di PT Sun Life Finansial cabang Singaraja".

$$
\text { Hasil menunjukkan bahwa }
$$

pelaksanaan penilaian kinerja karyawan amat penting dilakukan untuk membantu pihak manajemen dalam mengambil keputusan mengenai pemberian bonus, kenaikan jabatan, kenaikan gaji, pemindahan pada unit yang sama maupun pemutusan hubungan kerja dengan perusahaan. Untuk itu dibutuhkan informasi yang penting bagi keputusan penempatan tersebut adalah melalui penilaian kinerja. Dari penilaian prestasi ini dapat diketahui apakah penempatannya sudah tepat ataukah perlu dipindahkan ke bagian lain atau mungkin dipromosikan. Apabila ada kemungkinan untuk dipromosikan, maka karyawan diberi pendidikan lanjutan atau latihan tambahan yang diperlukan untuk menduduki jabatan yang direncanakan akan diduduki. Maka apabila jabatan yang dipersiapkan untuk karyawan ada yang kosong, maka karyawan telah siap untuk dipromosikan.

Hasil ini sejalan dengan teori yang disampaikan oleh Hasibuan (2014:69) yang menyatakan bahwa salah satu upaya yang diharapkan dapat meningkatkan kinerja karyawan adalah melalui program pengembangan pegawai. Pengembangan pegawai adalah suatu usaha untuk meningkatkan kemampuan teknis, teoritis, konseptual, dan moral pegawai sesuai kebutuhan pekerjaan/jabatan. Upaya pengembangan karier ini tidak bisa berhasil dengan baik tanpa adanya penilaian kinerja yang tepat dari pimpinan kepada karyawanya.

Hubungan karakteristik organisasi terhadap pengembangan karier. Berdasarkan hasil penelitian menunjukkan bahwa karakteristik organisasi memiliki hubungan yang lurus dan kuat terhadap pengembangan karier di PT Sun Life Finansial cabang Singaraja sebesar 0,778 yang didukung hasil pengujian hipotesis dengan uji t-test didapatkan bahwa thitung > t-tabel $(2,118>1,671)$ sehingga hipotesis diterima yakni "terdapat hubungan yang positif antara karakteristik organisasi terhadap pengembangan karier di PT Sun Life Finansial cabang Singaraja".

Hal ini menunjukkan bahwa karakteristik organisasi yang ada pada PT Sun Life Finansial cabang Singaraja apabila dikelola dengan baik tentu akan mempengaruhi karyawan dalam meningkatkan kinerjanya sehingga secara langsung akan mempengaruhi pengembangan karier masing-masing karyawan, dimana dalam suatu organisasi karier seseorang itu selain dipengaruhi oleh kemampuan yang dimiliki oleh individu juga tidak lepas dari peran organisasi. Keputusan pemindahan dan promosi khusus yang diambil manajemen karier merupakan hasil terakhir dari program pengembangan karier. Untuk dipromosikan diperlukan adanya penilaian, penyuluhan, latihan dan pendidikan.

\section{SIMPULAN DAN SARAN Simpulan}

Berdasarkan hasil penelitian dan pembahasan yang telah diuraikan sebelumnya, maka diperoleh kesimpulan bahwa terdapat hubungan yang positif antara karakteristik individu dengan pengembangan karier Di PT Sun Life Finansial cabang Singaraja yang didukung dengan hasil pengujian hipotesis menggunakan uji T-Test bahwa nilai thitung > nilai t-tabel sehingga hipotesis diterima yakni "terdapat hubungan yang positif antara karakteristik Individu terhadap pengembangan karier di PT Sun Life Finansial cabang Singaraja", terdapat hubungan yang positif antara penilaian kinerja dengan pengembangan karier di PT Sun Life Finansial cabang Singaraja yang didukung dengan hasil pengujian hipotesis menggunakan uji T-Test bahwa nilai t-hitung $>$ nilai t-tabel sehingga hipotesis diterima yakni "terdapat hubungan yang positif antara penilaian kinerja terhadap pengembangan karier di PT Sun Life Finansial cabang Singaraja", dan terdapat hubungan yang positif antara karakteristik organisasi dengan pengembangan karier di PT Sun Life Finansial cabang Singaraja yang didukung dengan hasil pengujian hipotesis menggunakan uji T-Test bahwa nilai thitung > nilai t-tabel sehingga hipotesis 
diterima yakni "terdapat hubungan yang positif antara karakteristik organisasi terhadap pengembangan karier di PT Sun Life Finansial cabang Singaraja".

\section{Saran}

Berdasarkan simpulan penelitian yang telah dipaparkan diatas, maka diajukan saran yaitu hendaknya PT Sun Life Finansial cabang Singaraja meningkatkan karakteristik Individu melalui kegiatan pengembangan pengetahuan dan keterampilan karyawan berupa pendidikan dan pelatihan sehingga akan berdampak pada peningkatan keahlian yang dimiliki karyawan dalam menunjang pengambangan karier kedepannya, melakukan penilaian kinerja setiap akhir tahun secara objektif sebagai gambaran kinerja pegawai serta hal ini juga membantu pihak manajemen dalam mengambil keputusan mengenai pemberian bonus, kenaikan jabatan, kenaikan gaji, pemindahan pada unit yang sama maupun pemutusan hubungan kerja dengan perusahaan serta memperhatikan dan mensosialisasikan karakteristik organisasi kepada karyawan bahwa karyawan memiliki support penuh dari perusahaan karena karakteristik organisasi yang ada pada perusahaan merupakan sebuah entitas sosial yang diarahkan oleh tujuan yang sudah ditentukan sebelumnya (goal directed), memiliki sistem yang akuntabel dan kegiatan terstruktur yang disengaja serta adanya batasan-batasan yang jelas sehingga hal ini tentu akan menunjang karier karyawan, serta bagi mahasiswa lain yang berminat meneliti masalah pengaruh karakteristik Individu dan penilaian kinerja terhadap pengembangan karier agar mengembangkan penelitian ini lebih lanjut dan mempertimbangkan variabel lain yang belum diuji dalam penelitian ini yang memiliki pengaruh terhadap pengembangan karier diantaranya adalah pendidikan dan pelatihan, pengalaman kerja, disiplin kerja serta motivasi kerja.

\section{DAFTAR PUSTAKA}

Bobihu, Yusran. 2009. Pengaruh Karakteristik Organisasi dan
Karakteristik Individu Terhadap Pola Pengembangan Karir Pegawai (Studi Kasus pada STMIK Dipanegara Makassar). Tesis tidak diterbitkan. Makasar: Universitas Hasanuddin

Frankel, J.R \& Wellen,N.E. 2008. How to design and Evaluate research in Education. New York: McGrawHill

Handoko, H. T. 2013. Manajemen Personalia dan Sumber Daya Manusia. Yogyakarta: BPFE

Hardjana, Agus. 2012. Training Sumber Daya Manusia yang Efektif. Yogyakarta: Kanisius

Hasibuan, Malayu. 2014. Manajemen Sumber Daya Manusia. Edisi Revisi, Cetakan ke delapan. Jakarta: Bumi Aksara

Husein. 2012. Pengaruh Lingkungan Kerja dan Karakteristik Individu terhadap Kepuasan Kerja Karyawan Hotel Melati di Kecamatan Banjarmasin. Skripsi tidak diterbitkan. Universittas Hasanuddin

Nur Indriantoro \& Bambang,S. 2002. Metode Penelitian Bisnis,Cetakan Kedua. Yogyakarta: BEE UGM

Mangkuprawira. 2014. Manajemen Sumber Daya Manusia Strategik. Jakarta: Ghalia Indonesia

Mathis, Robert L \& Jackson, John. 2012. Manajemen Sumber Daya Manusia .Jakarta : Salemba Empat

Nizwar, A.R. 2014. Analisis Pengaruh Karakteristik Individu dan Karakteristik Organisasi terhadap Pengembangan Karier pada Dinas Peternakan Dan Kesehatan Hewan ProvinsiSulawesi Selatan. Skripsi tidak diterbitkan. Makasar: Universitas Hasanuddin 
Notoatmodjo, $\quad$ Soekidjo. 2012. Pengembangan Sumber Daya Manusia. Jakarta: Rineka Cipta

Rivai, V. \& Sagala, E. J. 2013. Manajemen Sumber Daya Manusia untuk Perusahaan: Dari Teori ke Praktik. (Edisi II). Jakarta: PT Raja Grafindo Perkasa

Sedarmayanti. 2012. Manajemen Sumber Daya Manusia (Reformasi Birokrasi dan Manajemen Pegawai Negeri Sipil). Cetakan Kedua. Bandung: PT. Refika Aditama

Septiawati, Nise. 2012. Analisis Pengembangan Karier Pengaruhnya terhadap Kepuasan Kerja Karyawan pada Kantor Pusat PT. POS Indonesia (Persero) Bandung. Jurnal Manajemen \& Kewirausahaan.Vol 3 (No 1) : 625-639

Simamora, Henry. 2014. Manajemen Sumber Daya Manusia. Edisi Revisi. Jakarta: Ghalia Indonesia

Sugiyono. 2012. Statistika untuk Penelitian, Cetakan ke 21. Bandung: Alfabeta

Sumarsono, Sony. 2012. Metode Riset Sumber Daya Manusia. Yogyakarta: Graha IImu

Tajuddin, Sukma Juwati. 2012. Pengaruh Penilaian Kinerja Karyawan terhadap Pengermbangan Karier pada PT Semen Tonasa Kabupaten Pangkep. Skripsi tidak diterbitkan. Makassar: Universitas Hasanuddin

Thoha, Miftah. 2012. Perilaku Organisasi, Konsep Dasar dan Aplikasinya. Jakarta: Raja Grafindo Persada

Wahab. 2012. Anatomi Organisasi dan Kepemimpinan Pendidikan. Bandung: Alfabeta 